\title{
Analysis of Love, Death, Rebirth and Patriarchy in Two Contemporary Poetess Forough Farrokhzad and Sylvia Plath's Selected Poems
}

\author{
Narges Raoufzadeh ${ }^{1}$, Sharzad Mohammad Hosein ${ }^{2}$, Shiva Zaheri Birgani ${ }^{3}$ \\ ${ }^{I}$ Department of English Language and Literature, Science and Research Branch, Islamic Azad University, \\ Tehran, Iran. \\ ${ }^{2}$ Department of English Language and Literature, Tehran North Branch, Islamic Azad University, Tehran, Iran \\ ${ }^{3}$ Islamic Azad University, Masjed Soleyman, Khuzestan Province, Iran \\ raufzadehn@gmail.com
}

\begin{abstract}
Forough Farrokhzad and Sylvia Plath's poems are closely linked to their personal life and their marriage. Their poems are confessional in style. Farrokhzad criticizes Iranian male dominant society in which women are marginalized and haven't any voice in the society, so seeking their voice and identity in modern literature, especially in modern Persian poetry. Sylvia Plath attempts to resist patriarchy in her society through her poems too. Two poets highlighting and expressing the lack of interest in life and the sole desire to die in most of their poems. Not only poetic imagery and themes like death, frustration and failure are common points that convey pessimistic views in their poems, but also few of their poems convey optimistic elements of life and hope so this paper is going to explain them too. Farrokhzad and Plath, two contemporary female poets, attempted to gain a voice for women in their country. They are considered as the successful feminist voices in their countries and astonishingly share the same themes and issues in their poetry. The present paper aims to highlight characteristics of confessional poetry and elaborate on concepts of love, death, rebirth and patriarchy in ForoughFarrokhzad and Sylvia Plath's poems.
\end{abstract}

Keywords: Confessional poet; death; love; patriarchy; rebirth.

\section{Introduction}

Forough Farrokhzad (1935-1967) the famous Iranian contemporary poet, is the first modernist woman poet of Iran, and Sylvia Plath (1932-1963) one of the most appreciated poets of twentieth century. After Emily Dickinson, Sylvia Plath is the first important poet in American Literature. Her works influenced not only American poetry, but also the European poetry as well. Plath breaks taboos that women were not supposed to break in 50s through her confessional poems. Farrokhzad and Plath are contemporary confessional poets from the same era but different cultures and countries. Their view toward life and literature make these two poets similar. They share the same themes and concerns in their poetry and their lives. Studying biography of Farrokhzad and Plath, two contemporary poets, explores the main similarity between two poets, both had a tortured life and experienced separation, marginalization and disloyalty as a female poet. They were victims of male brutality and destroyed by their faithless husband. Their poetry is about death and darkness that convey pessimistic elements, disappointments, hopeless or negative aspects of their life. Few positive elements such as life and hopefulness are signs which also shines in their poems that we cannot ignore them. This paper tries to find both pessimistic and optimistic elements in the poetry of these two female poets. 


\title{
II. Discussion
}

\subsection{Confessional Poetry or "Confessionalism"}

It is the poetry of the personal or "I". This style of writing emerged in the late 1950s and early 1960s associated with poets such as Robert Lowell, Sylvia Plath, John Berryman, Anne Sexton, Allen Ginsberg and W.D Snodgrass. Plath and Sexton were Lowell's students, so he had a great influence on their own writing. The confessional poetry is a genre of poetry, first identified in the decades immediately following the second world war. The confessional poetry of the mid-twentieth century dealt with subject matter that previously had not been discussed in American poetry. Trauma, feelings and private experiences about death, depression and relationships were addressed in this type of poetry, often in an autobiographical manner. It was a reaction to the depersonalized, academic poetry of writers like T.S. Eliot and W.H. Auden, who wrote in 1920s and 1930s. They believed poetry was a thing apart from its creator and there wasn't any room for the self in poetry. However, the confessional poets did not obey this perspective, instead writing from a deeply personal perspective and filling their work with intimate and controversial details from their private lives.

\subsection{Concept of Love in Forough Farrokhzad's Selected Poems}

In Forough's poetry, the quality of love, it's existence and it's positive or negative meaning depended largely on the lover and beloved. If they were true and sincere in their love, it would represent itself truly and positively. The true and real face of love was shown and showed by a true lover. Forough believes that love must be something that help and promote one for achieving perfection. Forough's attitudes toward love was different. In her early poems due to being a young girl of seventeen or eighteen, her concept of love was more romantic and imperfect. It was an emotional or sensual reflection. A lot of her poems in her three collections The Captive, The Wall and Rebellion include this kind of love. Poems like "The Kiss", "Night and Passion", "Sin", "The Dawn of the Love" and "Tie" are some good examples of this love. Of course this love naturally was sometimes wished and sometimes rejected, her personal life and periods in which she was experiencing it were her best reasons for it.

\author{
If tomorrow didn't come \\ I would stay with you for ever \\ In the light of your sun \\ I would sing my song for ever \\ Forough rejects love in "In the Green Water of the Summer" \\ I left myself in a shad \\ In invalid shadow of love \\ In escaping shadow of happines \\ In the shadow of transient \\ Also in another poem "On The Earth" rejects love in this way. \\ On the ear \\ Of my cabin that is lif \\ Memories are carve \\ With the dark letters of love.
}


Forough found real love in poetry, poetry was her lost sweetheart, she experienced many kind of love and the only love that she found faithful was poetry.

$$
\begin{aligned}
& \text { But I, tired and wondered confused } \\
& \text { Pass the way of my wishes, } \\
& \text { My friend poetry and my sweetheart } \\
& \text { Pass to look for it. }
\end{aligned}
$$

After passing some years, her real personality was perfected as a result of facing life's unkindness and injustice, Forough found another meaning of love which was love of people. When she's speaking of their pain, she's actually showing her love towards them. Forough sincerely expresses her feelings and her concern for the people of her home land.

How I liked

Yahya to have a little cart,

And a little lantern

And how much I like

To sit among the watermelons and the melons

On Yahya's car

\subsection{Concept of Love in Sylvia Plath's Selected Poems}

Plath's early poems gives a beautiful picture of life which is based on personal emotions. She explains love as the measure of reality of man. But in her later poems, due to her experience, this measure of reality turns itself to something unreal and fake. For instance, the poem "Elm" shows all these changes. The poem was written for her close friend, Ruth Fainligh, for warning her against love. Her sense of hate toward love is quite obvious in this poem.

I know the bottom, she says,

I know it with my great tap root:

It is what you fear

Love is a shadow

How would you lie and cry after it

Listen: these are hooves: it has gone off, like a horse.

All night I shall gallop thus, impetuously,

Till your head is a stone, your pillow a little turf,

Echoing, echoing

In this poem, Plath forbids her friend of falling in love and being captured by it, since love is something unreal. She is confessing that she has made a mistake in her feeling, tells about her own experience of love which has been a failure and a bitter one that brought her to the edge of nothingness. Plath has an emphasis on her experience, "Love is shadow" is her concept of love now. Something unreal which sometimes is there and the other times is not, something which is vague and unclear. Something that has no identity, no essence of itself, so she warns her friend of falling in love for it will leave her soon in a deep grief which eventually ends to her death. She describes love as a wild horse that never stays in one place and never wishes and wants to be tamed. Plath emphasizes on the destroying and murderous 
nature of love that first petrifies will and then captures one wholly, It has nothing to give but a "snaky acids kiss"

\subsection{Concepts of Death and Rebirth in Forough Farrokhzad's Selected Poems}

Forough knew death as a ne of the rules of nature, a rule that gave man a sense of scorn.

Sometimes I feel that death is a rule of nature but it

is in the presence of this rule that man feels scornful.

It is a problem that nothing can be done with it

Even it cannot be battled with to be destroyed

There is no use in battling, it must be

It is very good as well.

Death doesn't have a limited meaning for Forough. By scrutinizing her poems one finds Forough's different views toward death. For instance, in Forough's poem "It is only voice that remains" death is taken as something natural and advised is to learn the essence and meaning of life.

Voice, voice, voice, it is only voice that remains

Remember flying

The bird will die.

In "Ali's Mother said to Him Once"Forough represents death as a way of redemption and salvation, a way of freedom from pains of life. In this poem Ali, a little boy is doubtful whether follow his dreams and achieve them or follow a materialistic life. While Ali is sitting on the edge of a pool, a fish invites him to join her and get free from this world.

A fish mover through the sea

Picks up star

Gone to someone's sleep

Make it heavy of stars, and the

Take him, take hi

From this world

Of the dead-hearty walls of the noise of clock

Unemployment, tiring

To the clean and pure waters of the $\mathrm{s}$

To the simplicity of the galaxy

In this poem Forough confesses her tiredness of this materialistic world and through death wants to make it over and put an end to it

\subsection{Concepts of Death and Rebirth in Sylvia Plath's Selected Poems}

Death and rebirth are major themes of Plath's poetry. Many of her poems are concerned with the Concept of death. The death of her father provoked her obsession with death and her poem "Daddy" reflects this fact. In this poem Plath has kept her dead father alive, at the time of her father's death she was ten years old. She could not forget him and his memory. In order to get back to him, she decided to resurrect him and then to kill him again. In her real life, she tried suicide as a way to reach him. Then she married a man who looked like him.

You stand at the blackboard, daddy.

In the picture I have of you.

A cleft in your chin instead of your foot. 
But no less a devil for that, no not.

Any less than black man who

Bit my pretty red heart in two

I was ten when they buried you

At twenty I tried to die

And get back, back, back, back to you.

I thought even the bones would do.

These lines taken from "Daddy" describe Plath's early attempt to suicide. She had a desire to be united again with her father and thought that death was her only way. In "Lady Lazarus" the speaker is obsessed with death, she attempted to commit suicide in the past.

I have done it again.

One year in every ten I manage it (1-3)

The speaker of "Lady Lazarus" is Lady Lazarus herself, she's extremely depressed and disturbed and shares a lot of similarities with Plath herself. Lady Lazarus compares herself to a Holocaust victim and tells about the first two times she almost died explains that dying "is an art" and a theatrical event. The poem starts to seem as if she's performing a third death in front of a crowd and at the end of the poem, she returns to life from death. So "Lady Lazarus" shows her preoccupation with death. It seems Plath is talking about her previous encounters with death. The first death was her father's death. Her second encounter with death was her suicide attempt at the age of nineteen, finally at the age of thirty, she successfully killed herself.

\author{
"Dying" \\ Is an art, like everything else \\ I do it exceptionally well. \\ I do it so it feels like hell. \\ I do it so it feels real. \\ I guess you could say I've had a call.
}

Throughout these lines, Plath demonstrates her eager to death. The image of children Plath uses a lot in her poems indicate the idea of rebirth. In "Face Lift" the idea of rebirth surfaces at the end with "Mother to myself... Pink and smooth as a baby" Plath is trying to say that the former self is trapped in a jar and now she is a new person, a baby. "Ariel", deals with the very personal issues of suicide, sex, her children and most dramatically, her complicated relationship with her deceased father. Poems like "Daddy", "Ariel" and "Lady Lazarus" are stunning in their originality, wit and brutality.

\title{
2.6.Effect of Patriarchy in Forough Farrokhzad Poems
}

According to almost all feminist scholar's patriarchy refers to rule of the father in a male dominated society as a social and ideological construct which regards men as superior to women. They are of opinion that men's domination over female sexuality is central to women's subordination. In fact, man is the head of the family who controls women's sexuality, labor, production, reproduction and mobility. Moreover, the effect of patriarchy can be traced in politics, public life and economy as well as in all aspects of social, personal, psychological and sexual existence. Farrokhzade criticizes Iranian male dominant society in which women are marginalized and haven't any voice in the society, so seeking their voice and identity in modern literature specially in modern Persian poetry. 


\section{Farrokhzad in The Captive Steates (Asir)}

$\mathrm{I}$, in this corner of the cage, I am a captive bird

This poem portrays the marginalized and imprisoned situation of Iranian women in the traditional frames of the society. She continues. directing toward you

From behind the cold and dark bars my rueful look of astonishment,

I am thinking that a hand might come and I might suddenly spread my wings in your direction.

I am thinking that in a moment of neglect

I might fly from this silent prison

Laugh in the eyes of the man who is my jailer

And beside you begin life anew.

I am thinking these things, yet I know that I cannot, dare not leave this prison. even if the jailer would wish it, no breath or breeze remains for my flight.

The idea of comparing the marriage to a cold, dingy jail, emphasizes the reasons as to why the lady wants to leave, to find a new life, or a new beginning, as well as when she states that she is a captive bird, she is hidden from the world. "From behind the cold and dark bars" This quote provides a vivid image of the life in which the speaker lives in, as it is in a "dark" worded phrase, the mental image that is created would be one full of unpleasant life. Farrokhzad encourages women for beginning a new free life and also want to make women free from the male dominated and men made rules, suppress and silence which society has imposed on them. In a patriarchal society in which women are drowned in innocent youth and are created to satisfy men's desires in The Captive Forough dared to express her controversial and heretical views about the limitation on and aspirations of Iranian women. She described herself as the bird who has been planning to fly for a long time and attacked the tyrannical attitudes of men toward women. In "Let Us Believe in the Beginning of the Cold Season") Farrokhzad looks into both the past and the future. Poem is a review of her whole life, a look at exciting past moments and empty present male dominated society. The last look of a drowning woman who is going to be silenced by patriarchy and marginalized in this society. Farrokhzad criticizes the hollow men of this society who silenced women and are savage creatures that know nothing about social injustice.

$$
\text { Hollow man }
$$

Hollow man, full of faith

Look! His teeth

Chew at songs

And his eyes

Devour while staring

These hollow men are in the center of power, enjoying their happy savage life in a society formed by male domination, where there is no place for women and they are treated as object. 


\section{Happy corpses \\ Weary corpses \\ Thoughtful silent corpses}

Farrokhzad portrays these hollow men as knowing nothing about justice. In such a society built by tyrant men, women have no right as they are objectified. In her famous poem "Window" Farrokhzad wishes a window for overcoming her hopelessness, shows that law is dark and justice has no meaning and the patriarchal society dehumanizes women and provides no voice for them in the society.

When my trust was suspended from the fragile thread of justice and in the whole city they were chopping up my heart's lanterns when they would blindfold me with the dark handkerchief of desire and from my anxious temples of desire fountains of blood would squirt out when my life had become nothing nothing

but the tic-tac of a clock (Farrokhzad's Window)

Then Farrokhzad asks for a rescuer to complain the dark history of the massacre of women in the male dominated society of Iran and other countries, believing that all women are marginalized by patriarchy and indirectly shows that all women all over the world have the same condition.

Oh friend! O brother! O blood fellow!

when your reach the moon

write the history of the massacres

of flower

Farrokhzad believes that the only way for ending such a cheerless and miserable patriarchal life is death which soon or late will come to her and makes her free from all limitations and boundaries of the male- dominated society.

My death will come someday to me one bittersweet day, like all my days one hollow day like the one past shadow of today or of tomorrow. my eyes tune to half dark hallways my cheeks resemble cold, pale marble suddenly sleep creeps over me I become empty of all painful cries. (Farrokhzad'sLater On)

\subsection{Effect of Patriarchy in Sylvia Plath's Poems}

Plath in "Lady Lazarus", "Daddy" and "The Bell Jar" attempting to resist patriarchy; Firstly, she portrays the lives of women in which social, historical, political and psychological oppression is a reality, through the gendered definitions that limit and oppress in society. And secondly, these three poems are a reaction to the strict frames that dictate what it means to be and is expected of a woman. "Daddy" and "Lady Lazarus "are poems filled with images of the hatefulness of marriage and the powerlessness of women caught in 
the marriage trap. In "Daddy" there is a monstrous, but at the same time idealized male figure, addressed in a both childlike perspective and a full-grown woman's rage. It's a strong and bitter poem that addressed the place from which the woman wants to liberate herself. The poem begins with the lines:

Daddy, I have had to kill you.

You do not do, you do not do

Any more, black shoe

In which I have lived like a foot

For thirty years, poor and white,

Barely daring to breath or Achoo. (1-5)

"Daddy" concern her troubled relationship with her authoritarian father and her feeling of betrayal when he died. The poem contains references to the Holocaust but uses a sing-song rhythm that echoes the nursery rhymes of childhood.

\section{Conclusion}

Farrokhzad and Plath, two contemporary female poets, attempted to gain a voice for women in their country. They are considered as the successful feminist voices in their countries and astonishingly share the same themes and issues in their poetry. Farrokhzade criticizes Iranian male dominant society in which women are marginalized and haven't any voice in the society, so seeking their voice and identity in modern literature specially in modern Persian poetry. Sylvia Plath attempts to resist patriarchy in her society through her poems too. They share not only, poetic imagery and themes like death, frustration and failure are common points that convey pessimistic views in their poems, but also few of their poems convey optimistic elements of life and hope. Love for ForoughFarrokhzad and Sylvia Plath hasn't remained in the same quality as it has been perceived before. They have had a common experience of love and came to this conclusion that love finds its quality from the one who claims it.

If he is a true lover, love will be true and if he is not the right one, it will be unreal. So one of the most important differences between Forough and Plath is in their attitudes toward love. For Forough love started from a personal feeling toward another one and then step by step it turned into a love of the others, people. While in Plath love remained in the same level of personal feelings toward another one. Forough's view toward death was an ordinary one, she used to look at it and accepted it as it was, even believed on usefulness of death. She never wished to reject death. She thought of death as a necessary thing. For Forough, like the other poets, death is a peace of mind "And earth, the earth that receives, invites to tranquility". Plath wanted to achieve a psychological peace and relaxation, she found it through death. Plath experienced death in order to kill her fear of it. She went to a battle with death for proving herself. Plath looked at death as a way of escaping and being free.

\section{References}

Basirizadeh, Fatemeh. (2019). A Comparative Study of the Psychoanalytical Portrayal of the Women Charactersby Virginia Woolf and Zoya Pirzad. Britain International of Humanatis and Social Sciences Journal, 1-8. 
Brookshaw, Dominic \& Nasrin Rahimieh. (2010). Forough Farrokhzad: Woman Poet and Icon, London and New York: I.B. Tauris.

Gill, Jo. (2006). The Cambridge Companion to Sylvia Plath. New York: Cambridge University Press.

The Cambridge Introduction to Sylvia Plath. (2008). United States of America: Cambridge University Press.

Meneses, Sandra \&Sodertons, Hogskola. (2009). Cultural Critique in a Patriarchal World. Revolutionary Suicide in Sylvia Plath's "Lady Lazarus", "Daddy" and "The Bell Jar". (2009). Soderton University.

A Brief Guide to Confessional Poetry Web 30 September 30, 2017 